\title{
The Livestock Roles in the Wellbeing of Rural Communities of Timor-Leste
}

\author{
Elisa Maria Varela Bettencourt ${ }^{1}$, Mário Tilman², Vanda Narciso ${ }^{3}$, \\ Maria Leonor da Silva Carvalho ${ }^{4}$ and Pedro Damião de Sousa Henriques ${ }^{5}$
}

\begin{abstract}
The livestock species play very important economic and socio-cultural roles for the wellbeing of rural households, such as food supply, source of income, asset saving, source of employment, soil fertility, livelihoods, transport, agricultural traction, agricultural diversification and sustainable agricultural production. The aim of this work was to identify and characterize the different roles that livestock and livestock species play in rural communities of TimorLeste, highlighting the importance of animal production for the wellbeing and rural development, and relate the functions performed by livestock production with economic, social and cultural attributes of the communities. The data used in this study were collected in 2011 through a questionnaire survey in three rural communities in the district of Bobonaro, namely in a mountain area, an irrigation plain and a coastal zone, and were complemented with secondary data. Livestock production in Timor-Leste is predominantly familiar being chickens, pigs, goats, cattle, horses, buffaloes and sheep the main species. Beyond the economic function, each livestock species also performs social and cultural functions.
\end{abstract}

Key-words: Timor-Leste, livestock, wellbeing, development.

JEL Classification: Q1, Q12, Q19, O13.

http://dx.doi.org/10.1590/1234-56781806-94790053s01005

1. Professora auxiliar, Departamento de Medicina Veterinária da Universidade de Évora and ICAAM, Apartado 94, 7000 Évora, Portugal. E-mail: emvb@uevora.pt

2. Professor, Universidade Nacional Timor Lorosa'e, Díli, Timor-Leste,mfvista_5@yahoo.com

3. Independent researcher, Portugal. E-mail: vandanarciso@gmail.com

4. Professora associada, Departamento de Economia da Universidade de Évora and ICAAM, Apartado 94, 7000 Évora, Portugal. E-mail: leonor@uevora.pt

5. Professor asociado, Departamento de Economia da Universidade de Évora and CEFAGE, Apartado 94, 7000 Évora, Portugal. E-mail: pdamiao@uevora.pt 


\section{Introduction}

The livestock species play very important economic, social and cultural roles or functions for rural households once they contribute to improve income and wellbeing of the farm family. Livestock helps on food supply, family nutrition, family income, asset savings, soil productivity, livelihoods, transport, agricultural traction, agricultural diversification and sustainable agricultural production, family and community employment, ritual purposes and social status (MOYO et al., 2010).

Livestock functions can be classified in several ways. According to FAO (ILRI, 1995), two widely used classifications are based on the kinds of output produced or in the uses in which these outputs are put on. Among the kinds of output produced it should be mentioned the food, inputs to cropping, and raw materials. Among output uses, subsistence consumption by the livestock holder's household, direct supply of inputs, cash income through sales of live animals or their output, savings and investment and social functions such as paying bride wealth, or providing animals for communal feasts or sacrifices can be pointed out.

Another classification divides livestock functions in economic roles such as source of cash income and mean of savings accumulation, direct feed use for family subsistence, input supply such as fertilizer and animal draught and capacity to comply with a set of social rules and obligations.

Livestock has an important contribution for food supply of rural and urban areas and contributes to the family nutrition, supplying animal protein. As household income increases, the consumption of protein increases, principally from animal origin, allowing the substitution of vegetal by animal protein. Besides milk, eggs and meat used as a source of food, other livestock products are used for domestic consumption and local sale such as skins, hides and horns.

Livestock feature as living savings can be converted into cash whenever the family needs it, is a security asset influencing access to informal credits and loans and being also a source of collateral for loans. In many rural regions, in special where financial markets are absent or nonexistent, livestock stocks or herds are a source of asset accumulation and a measure of prosperity. Livestock stocks or assets can be mobilized at any time, satisfying planned expenditures such as children school fees and bride wealth or unplanned expenses such as the illness and death of family members. This livestock asset could be seen as "bank account" and it is also an important source of family savings that can be used in years of low crop production, reducing income insecurity and household vulnerability, being an important source of risk reduction and security increase. 
Livestock production is closely interrelated with crop production. The use of livestock and its sub product manure are important in crop production. Livestock is a source of energy providing draught animal power while manure improves soil structure and fertility as well as water retention. Both uses are environmentally friendly improving energy and nutrient cycling. Livestock is also used to transport agricultural inputs and outputs and people.

Livestock production is an important mean of exchange between rural households and, when sold, contributes to boost and strengthen rural markets. Rural markets are an important piece in the operation mode of rural communities and a significant contribution for rural families' wellbeing and wealth.

The livestock social functions correspond to the symbolic values associated to each species and the use of animals for the fulfillment of a set of rituals and social obligations of families and communities. Livestock gives social status to its owners once it is considered a common mean of demonstrating wealth and provides economic status as it facilitates the access to informal credits and loans to the households. Livestock is also used in traditional rituals, ceremonies and festivities and is given as a gift in worships (e.g. installation of ancestral spirits, ritual slaughter, bride wealth).

In some cultures, animals can be considered sacred (cattle in India) and in others cultures (pigs in Muslim countries) animals are impure. For both these cultures, those species are not consumed by the population. In other countries or cultures, animals play an important leisure role, being used for betting, like horse racing and cock fighting, for sports, like horses in polo and bullfighting and for hunting, like dogs, falcons and horses.

Animal health greatly affects livestock functions, not only by direct effects on animal productivity but also by indirect effects, namely concerning human health, coasts associated to disease control, international movement restrictions of animals and animal products as well as animal welfare (OTTE and CHILONDA, 2000).

Concerning the direct effect on productivity, it can be due not only to the mortality and reduction of livestock herds, but also, due to the decrease on productive parameters, namely weight gain or milk production, or even through the decrease of quality of animal products. The existence of a great number of parasitary, infectious or metabolic diseases that affect fertility cannot be underestimated, despite the difficulty to quantify the associated costs.

Besides the positive effects of livestock to human welfare, livestock production and consumption can also be associated to some risks, namely the transmission of important diseases that are transmitted from animals to humans (zoonosis). The absence of rigorous animal health control programs represents a high risk to the human health. Moreover the rigorous control and restrictions to animal movementand to exportation of animal products, associated with the existence of animal disease, makes the existence of national animal health programs indispensable in order to allow international trade.

The social and cultural functions of livestock are often ignored when estimating the total contribution of livestock to the development and well-being of rural communities. Since those functions are difficult to value in monetary terms, emphasis is mainly placed on the physical marketed livestock production. One key to smallholder competitiveness is its ability to capture non market benefits, however not well measured to date (OUMA et al., 2003).

It is relevant to know the present functions of the livestock sector, and to understand that expanding the output of one function may diminish the output of another. So, in order to evaluate its importance, from different points of views, and to ensure correct policies and practices, all of them have to be taken in consideration.

Livestock production in Timor-Leste is predominantly familiar, the main species including chickens, pigs, goats, horses, cattle, buffaloes and sheep, and each one performing several functions for rural communities and families.

The aim of this work is, for three rural communities in the district of Bobonaro mountain area, irrigation plain and coastal zone 
-, to identify and characterize the different roles that livestock and livestock species play in rural communities, highlighting the importance of animal production for the wellbeing and rural development, and relate the functions performed by livestock production with economic, social and cultural attributes of the communities.

The primary data used in this study was collected in 2011 through a questionnaire survey and complemented with secondary data from different consulted sources. The farmers survey was conducted in three sucos, Tapo-Tas, Tapo-Memo and Aidabaleten, of the district of Bobonaro, where 101 households were selected by convenience sampling. The 13 districts of East Timor are subdived in 67 subdistricts and those are subdivided into 442 villages-sucos - and 2,336 communities or hamlets - aldeias. The questionnaire characterized the economic and the sociocultural functions that livestock production plays in the life, wellbeing and development of rural households and communities. The secondary data used included the studies made during Portuguese colonial period and after the 1999 referendum and the data collected in the different livestock census, in special the 2004 and 2010 census. The analysis performed was essentially descriptive and qualitative, highlighting the functions that livestock still performs in the rural communities of Timor-Leste.
After this introduction, in the second part livestock production in Timor-Leste is characterized, in the third section the functions of livestock production and species in TimorLeste are explained and in the final part the main conclusions are drawn.

\section{Livestock production in Timor-Leste}

Regarding livestock production in TimorLeste, it is important to remember that sheep and cows were introduced sometime in the past, after the arrival of the Portuguese and Europeans in the territory and that at the beginning of the $X X$ th century the number of cattle was very small, in 1920 was 617, and only in 1954 reached more than 10,000 heads.

The evolution of the number of livestock heads during the last century shows three moments in which the livestock stocks were severely reduced: second world war, beginning of the war for independence or beginning of Indonesian occupation and referendum for independence, as can be seen in Figure 1, where the number of livestock heads is expressed in terms of livestock standard units (LSU). The LSU at the end of Portuguese colonization is very similar to the one observed nowadays. However, LSU per capita is

Figure 1. The evolution of the number of livestock standard units((LSU) in Timor-Leste

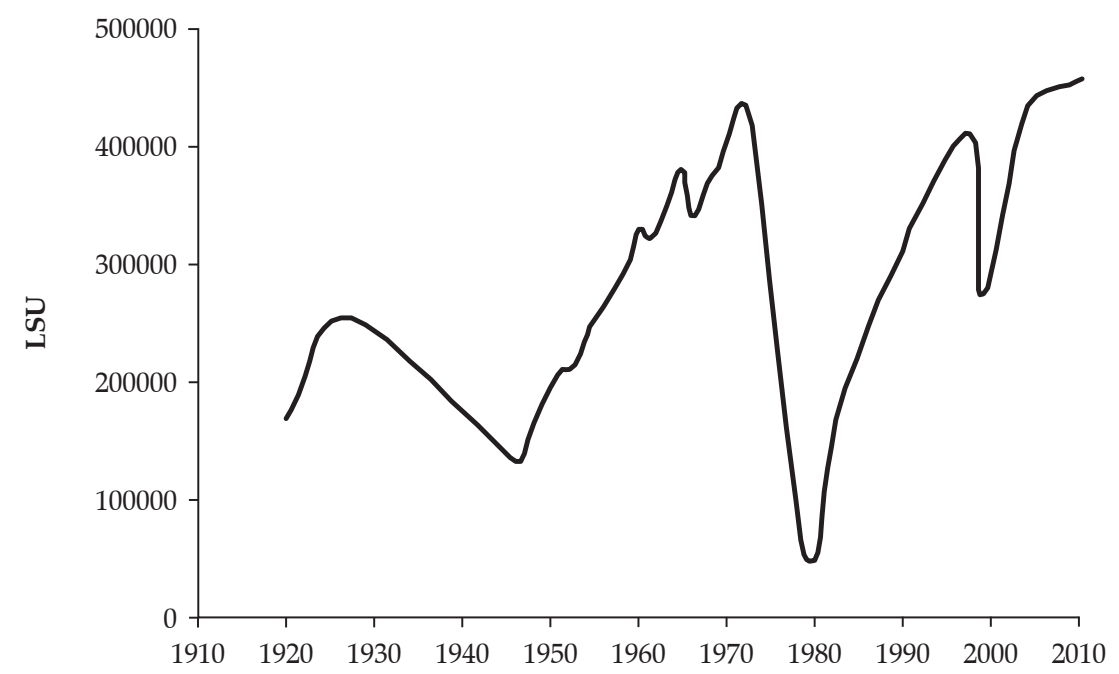

Source: Elaborated by authors. 
lower nowadays due to the population growth that was observed during the last 40 years. At the end of Portuguese colonization, LSU per capita were around 0.65 while nowadays is around 0.43 .

A comparative static analysis can be made between the different historical periods (Table 1). For instance, between the end of Portuguese colonization (1970) and nowadays (2010), cattle increased 2.3 times, buffalos decreased $25 \%$, horses decreased $50 \%$, pigs increased 1.5 times and goat decreased $30 \%$.

The majority of rural households and a significant number of urban households own some sort of livestock, $76.63 \%$ of the total number of households rear livestock. Livestock species, per order of importance in head numbers, are chicken, pigs, goats, cattle, horses, buffalos and sheep (DNE 2006; DNE 2011). Between 2004 and 2010, the number of heads increased for all species reported, excepted for horses.

From the household point of view, the most important livestock species are chickens and pigs. In 2004, more than $70 \%$ of the households owned these two species, while, in 2010, that percentage decreased to around $67 \%$. The percentage of households with cattle and goats is around $20 \%$, and between 2004 and 2010 there was an increase in the number of household holders of 8.3 and $9.3 \%$, respectively. In the same period, the households with horses decreased $19.3 \%$, from $17.6 \%$ to $15.0 \%$, while households with buffalos decreased $13.6 \%$, from 11.3 to $10.4 \%$. The percentage of household with sheep is small, around $4 \%$, with a reduction in the period of 11.9\%. In overall terms, between 2004 and 2010, only in cattle and goat production, there was an increase in the number of households involved in those livestock activities.

The average number of heads of livestock per household is low, but some large producers are found throughout the country. In 2010, the average number of heads is 6 for sheep, 5.6 for chicken, 5.0 for buffalos, 3.8 for cattle, 3.3 for goats, 2.7 for pigs and 2.1 for horses. Between 2004 and 2010, the average number of livestock heads per household increased. The reduction in the number of households involved in livestock production and the increase in livestock density per family is a phenomenon that often happens simultaneously (Table 2).

Table 1. Number of livestock heads in Timor-Leste during the last century

\begin{tabular}{ccccccccc}
\hline & Cattle & Buffalos & Horses & Pigs & Sheep & Goats & LSU & LSU per capita \\
\hline 1927 & 1477 & 126356 & 73028 & 121225 & 47171 & 146122 & 254075 & 0.563 \\
1946 & 881 & 64073 & 38487 & 73371 & 21051 & 52708 & 132468 & 0.329 \\
1970 & 70607 & 127148 & 114152 & 224268 & 43033 & 217011 & 404788 & 0.640 \\
1983 & 39705 & 40229 & 21584 & 202242 & 17751 & 74062 & 187279 & 0.297 \\
1997 & 146557 & 73818 & 32792 & 362473 & 20391 & 202934 & 413930 & 0.491 \\
2010 & 161654 & 96484 & 57819 & 330435 & 41854 & 152360 & 455989 & 0.428 \\
\hline
\end{tabular}

Source: Elaborated by authors.

Table 2. Households producing the different livestock activities in 2004 and 2010

\begin{tabular}{ccccccccc}
\hline \multirow{2}{*}{$\begin{array}{c}\text { Livestock } \\
\text { Species }\end{array}$} & \multicolumn{2}{c}{$\begin{array}{c}\text { Number of livestock } \\
\text { (heads) }\end{array}$} & \multicolumn{2}{c}{$\begin{array}{c}\text { Number of households } \\
\text { involved }\end{array}$} & $\begin{array}{c}\text { \% of households } \\
\text { with livestock }\end{array}$ & \multicolumn{2}{c}{$\begin{array}{c}\text { Number of livestock } \\
\text { per household }\end{array}$} \\
\cline { 2 - 9 } & 2004 & 2010 & 2004 & 2010 & 2004 & 2010 & 2004 & 2010 \\
\hline Chickens & 659066 & 702474 & 141372 & 124658 & 72.5 & 67.5 & 4.7 & 5.6 \\
Pigs & 331895 & 330435 & 140697 & 123862 & 72.2 & 67.1 & 2.4 & 2.7 \\
Goats & 126977 & 152360 & 41902 & 45781 & 21.5 & 24.8 & 3.0 & 3.3 \\
Cattle & 133577 & 161654 & 39713 & 43028 & 20.4 & 23.3 & 3.4 & 3.8 \\
Horses & 63234 & 57819 & 34314 & 27691 & 17.6 & 15.0 & 1.8 & 2.1 \\
Buffalos & 95921 & 96484 & 22127 & 19119 & 11.3 & 10.4 & 4.3 & 5.0 \\
Sheep & 38965 & 41854 & 7897 & 6957 & 4.1 & 3.8 & 4.9 & 6.0 \\
\hline
\end{tabular}

Source: DNE 2006 and 2011. 
As expected, the percentage of urban households with livestock is much lower than those of rural households. Around $79.9 \%$ of rural households have some sort of livestock production and only $56.1 \%$ of urban households do.

The more relevant livestock species for urban households are chickens and pigs, 41.3 and $41.0 \%$, respectively. Regarding the average number of livestock heads per household, urban areas show higher stock rates for all the species, except for pigs (Table 3).

The comparison between 2004 and 2010 of urban and rural households that rear livestock shows that the number and proportion of urban households with chicken and pigs decreased, while the number and proportion of urban households with sheep increased. Regarding livestock heads, the urban number and proportion of heads increased for chicken and sheep and decreased for pigs.

Concerning the percentage of households involved in the production of each animal species, per district, one can conclude that the importance of pigs and chicken is similar in almost all the districts (around 70\%), with exception for the urban district of Díli (around 30\%) and Liquiça (84\% and $82 \%$, respectively for chicken and pigs). Covalima, Bobonaro and Oecussi are the more representative districts concerning cattle production, with almost half of households owning cattle (Covalima 49.3\%, Bobonaro 43.3\% and Oecussi $44.5 \%$ ). Household engagement in buffalo production is higher in Viqueque $(24.2 \%)$, Lautem (22.3\%), Manatuto (19.2\%), Manufahi
(19.2\%) and Ainaro (15.3\%).The most important districts involved in goat production are Liquiça (50.1\%) Aileu (39.7\%), Oecussi (35.6\%), Manatuto (32.8\%) and Baucau $(30.2 \%)$ and sheep production is mainly restricted to Baucau and Manatuto districts, respectively with $17.8 \%$ and $6.1 \%$ of the households involved. Horse distribution is higher in the mountainous districts, Ainaro (37.5\%), Manufahi (29.7\%), Manatuto (25.5\%), Baucau (24.7\%) and Aileu (24.0\%).

Regarding the distribution of livestock species per district, in overall terms, the districts of Baucau, Viqueque and Bobonaro are the ones that show higher proportion of livestock heads. For chicken, the order is Baucau, Viqueque and Bobonaro, for pigs Bobonaro, Baucau and Viqueque, for goats Baucau, Bobonaro and Liquiça, for cattle Bobonaro, Viqueque and Covalima, for horses Baucau, Viqueque and Ainaro, for buffalos Viqueque, Baucau and Lautem and for sheep Baucau with more $55 \%$ of total heads (Table 4).

Crossing livestock heads with households involved in production, Table 5 shows animal densities per household and district. Regarding chickens, heads per households are higher in Lautem and Viqueque, for pigs in Viqueque and Lautem, for goats in Viqueque, Díli and Lautem, for cattle Viqueque and Lautem, for horses in Díli, Viqueque and Lautem, for buffalos Viqueque Manatuto and Lautem and for sheep Oecussi and Manatuto. In overall terms, animal producers of Viqueque and Lautem are the ones with higher animal herds.

Table 3. Comparison of livestock in rural and urban households for 2010

\begin{tabular}{ccccc}
\hline \multirow{2}{*}{ Livestock Species } & \multicolumn{2}{c}{ Percentage of households } & Number of livestock per household \\
\cline { 2 - 5 } & Urban & Rural & Urban & Rural \\
\hline Chickens & 41.3 & 76.7 & 6.3 & 5.5 \\
Pigs & 41.0 & 76.2 & 2.3 & 2.7 \\
Goats & 9.0 & 30.3 & 4.0 & 3.3 \\
Cattle & 6.9 & 29.0 & 4.0 & 3.7 \\
Horses & 2.7 & 19.3 & 2.8 & 2.1 \\
Buffalos & 3.3 & 12.8 & 6.3 & 4.9 \\
Sheep & 1.8 & 4.4 & 7.7 & 5.8 \\
\hline
\end{tabular}

Source: DNE 2011. 
Table 4. Livestock distribution per district (\%)

\begin{tabular}{|c|c|c|c|c|c|c|c|}
\hline & Chicken & Pig & Goat & Cattle/Cow & Horse & Buffalos & Sheep \\
\hline Ainaro & 4.6 & 5.0 & 4.1 & 4.0 & 11.0 & 5.1 & 2.6 \\
\hline Aileu & 3.4 & 3.8 & 3.9 & 2.9 & 4.3 & 1.8 & 2.0 \\
\hline Baucau & 12.0 & 10.7 & 17.0 & 3.8 & 20.8 & 15.1 & 55.2 \\
\hline Bobonaro & 10.9 & 12.3 & 11.8 & 18.1 & 5.8 & 7.8 & 4.9 \\
\hline Covalima & 6.8 & 9.6 & 4.6 & 13.8 & 2.8 & 2.6 & 1.7 \\
\hline Dili & 9.9 & 8.6 & 9.5 & 2.2 & 2.5 & 1.5 & 4.3 \\
\hline Ermera & 9.3 & 8.3 & 6.1 & 7.0 & 6.1 & 3.9 & 2.9 \\
\hline Liquiça & 6.8 & 6.8 & 10.8 & 5.0 & 2.6 & 2.4 & 1.8 \\
\hline Lautem & 9.6 & 7.5 & 5.6 & 10.4 & 10.5 & 15.9 & 5.9 \\
\hline Manufahi & 5.2 & 5.0 & 3.3 & 4.7 & 7.3 & 6.1 & 0.9 \\
\hline Manatuto & 3.5 & 4.3 & 5.6 & 3.8 & 5.4 & 8.9 & 9.7 \\
\hline Oecussi & 6.6 & 7.6 & 8.8 & 10.2 & 2.4 & 1.9 & 2.5 \\
\hline Viqueque & 11.6 & 10.5 & 8.9 & 14.0 & 18.7 & 26.9 & 5.7 \\
\hline Timor-Leste & 100.0 & 100.0 & 100.0 & 100.0 & 100.0 & 100.0 & 100.0 \\
\hline
\end{tabular}

Source: DNE 2011.

Table 5. Number of livestock units per household and per district

\begin{tabular}{cccccccc}
\hline & Chicken & Pig & Goat & Cattle/Cow & Horse & Buffalos & Sheep \\
\hline Ainaro & 4.6 & 2.3 & 2.7 & 3.8 & 1.8 & 3.3 & 4.4 \\
Aileu & 4.5 & 2.2 & 2.1 & 2.2 & 1.5 & 2.2 & 3.6 \\
Baucau & 5.1 & 2.2 & 4.0 & 4.1 & 2.3 & 5.1 & 6.1 \\
Bobonaro & 5.9 & 3.1 & 3.3 & 4.0 & 1.7 & 4.1 & 6.4 \\
Covalima & 5.9 & 3.6 & 3.7 & 4.1 & 1.6 & 3.8 & 7.1 \\
Dili & 5.8 & 2.3 & 4.0 & 4.6 & 4.6 & 4.2 & 5.8 \\
Ermera & 4.7 & 2.1 & 2.4 & 2.4 & 1.6 & 2.7 & 3.2 \\
Liquiça & 5.5 & 2.6 & 3.2 & 2.4 & 1.6 & 4.1 & 6.0 \\
Lautem & 7.9 & 3.1 & 4.3 & 5.9 & 2.7 & 6.0 & 6.8 \\
Manufahi & 6.1 & 2.9 & 3.0 & 3.7 & 1.8 & 4.3 & 3.3 \\
Manatuto & 4.9 & 2.8 & 3.8 & 3.9 & & 6.4 & 9.5 \\
Oecussi & 4.5 & 2.5 & 2.7 & 2.7 & 2.0 & 3.5 & 11.7 \\
Viqueque & 7.6 & 3.5 & 4.1 & 6.6 & 2.8 & 7.7 & 5.1 \\
Timor-Leste & 5.6 & 2.7 & 3.3 & 3.8 & 2.1 & 5.0 & 6.0 \\
\hline
\end{tabular}

Source: DNE 2011.

Livestock feeding is done using native pastures, crop and fallow land, agricultural products and waste materials around houses and villages. No grazing management rules of natural pastures leads many times to overgrazing and unsustainable animal production due to loss of the cover vegetation and enhanced soil erosion. Native pastures available occupy an area of around 200,000 ha, about $10 \%$ of the country area (CRUZ, 2003). The average number of cows and buffalos per ha of native pasture is around 1.,3 heads, higher than 3 for the districts of Dili, Aileu and Ermera and less than 1 for Lautem, Covalima and Manufahi,.
In overall terms, animal production is performed without any special concerns regarding feeding, reproduction or even health management. Animals are kept all together around the year, eating what is available, reproducing around all the seasons and fighting most of the diseases based only in their natural resistance. Vaccination is performed only for a few diseases, namely haemorrhagic septicaemia in cattle and buffalos; classic swine fever in pigs and Newcastle disease in chicken. However, as there is no consistent official animal identification, is difficult to evaluate the overall efficacy of its application. 
Pigs and goats are mostly free ranging, some being housed near human houses and sometimes feeding with domestic feed debris. Chicken are almost raised as scavenging birds. Some times are housed at night and feed with domestic feed debris.

Buffalos, cattle and sheep are raised free in native pastures. Changes in feed quality are seasonal and associated with changes in rainfall, which results sometimes in inadequate feed supply. Problems of inadequate feeding are more frequently associated with inadequate quality, namely low protein content, than with complete absence of aliment and sometimes are due to poor feed resources utilization (SMITH, 1992). The low quality of native grasses namely in the dry season, in which protein contents can fall below $4 \%$, and the inability of the traditional grazing management methods to improve pasture utilization and enrichment are good examples of cattle and buffalo production constrains (TIMOR AGRI, 2004).

In many situations, livestock underfeeding is observed but no feed supplements are supplied. Actually, in some areas, cattle and buffalos are supplemented with leguminous trees, namely Gliricidia sepium and Leucaena leucocephala. However, and as referred in the past, at the present time frequently the nutrition of livestock species and working horses is often neglected and many still suffer from hunger (CRUZ, 2003).

Despite the lack of reliable information on reproductive data, there is consensus that livestock fertility rate is low. The absence of a defined reproductive season and the associated nutritional constrains described above, as well as the possible existence of diseases affecting fertility can be responsible for this situation. The low fertility will affect animal selection and genetic progress. Moreover, the use of male animals in some rituals may have important consequences on fertility, mainly if the younger and better animals are the selected ones, staying in the farms only the older males to be used in reproduction. Recently, a survey was conducted by MAF (Minister of Agriculture and Fishery), with the support of the Faculty of Veterinary Medicine of Bogor University. The results show high serological prevalence of Brucellosis in cattle and buffalos in some districts of East Timor, which can be in part responsible for this low fertility (CONCEIÇÃO, 2012). More research is needed in order to understand the real impact on fertility of this disease.

Local livestock species, such as chicken and pigs, are more valuable than the imported ones. Regarding the gender divisions, usually women take care of small animals that live around the house, chicken and pigs, and men of the others, goats, buffalos, horses and cattle (our observations and MIRANDA, 2011).

Regardless the importance of livestock species in Timor-Leste, few studies have been performed in animal health distribution and no diseases are reported in OIE database (OIE, 2012).

In the past, surra (Trypanosoma evansi) and hemorrhagic septicemia (Pasteurella multocida) have been described as causing high mortality in Timor-Leste, namely in buffalos (VALDEZ, 1927; VALDEZ 1929; SILVA, 1954). Moreover, Silva (1960) performed a parasitic prospection in Timor-Leste in which he describes the internal and external parasitic fauna existent in the island, including Trypanosoma evansi, Fasciola hepatica Ascaris lumbricoide,Taenia solium and Coccidea sp. as well as a variety of ticks, namely; Amblyoma cyprium cyprium, Boophilus microplus, Haemaphysalis papuana, Rhipicephalus haemaphysaloides, Rhipicephalus sanguineus, which are well known vectors of important animal diseases. A recent parasitic prospection (CONCEIÇÃO, 2012), conducted by MAF with the cooperation of Bogor University, showed the presence of parasites in cattle, buffalos and pigs. The parasites identified with higher prevalence in cattle and buffalos were Anaplasma sp. (26.4\%), Babesia sp. (23.4\%), Theileria sp. (19\%), and Coccidia sp., in $11.9 \%$ of the samples. In pigs the more frequent parasites included Coccidia sp. $(24.6 \%)$, Eperythrozonn sp. (24.5\%) and Ascaris sp. (17.6\%).

Nowadays, Timor-Leste official veterinary services developed and applied veterinary 
programs concerning the control of some animal diseases, namely, as referred, hemorrhagic septicemia in cattle and buffalo, classic swine fever in pigs and Newcastle disease in chicken. The serological survey conducted by MAF, referred earlier in this text, also included the serological evaluation concerning the agents of these diseases. Positive serology was found in buffalos and cattle for Brucellosis and for Pasteurella multocida (hemorrhagic septicemia), in pigs for the virus of classic swine fever and in chicken for the virus of Newcastle disease and Infectious Bursal disease (CONCEIÇÃO, 2012).

Concerning the zoonotic diseases, the risk is highly improved due to the absence of animal official identification and routine animal health controls, indispensables for the control of important zoonosis, namely brucellosis and tuberculosis. The recent confirmation of the presence of Brucellosis in cattle and buffalos (FELICIANO, 2012) emphasize the urgent need of developing an official program for the control of this important disease. Moreover some livestock animals, namely pigs, are important reservoirs of emergent diseases in humans, namely Japanese encephalitis, which have been recently identified in Timor-Leste (WHO, 2012). Because pigs are mostly free ranging, some being housed near human houses, the risk for encephalitis is higher in the rural areas where rice fields and pigs coexist.

\section{The functions of livestock production and livestock species in Timor-Leste}

The descriptions made by the Portuguese during the XX century about Timor-Leste livestock species talk about buffalos, cattle, horses and pigs as a symbol of wealth, being the greatness of a king, chief or a simple man of the people, assessed by the number of animals or herds owned.

Although there were significant livestock numbers and the fact that animals are an important source of proteins, the population rarely consumed their animals at home, except during funerals or feasts. Animals were a way of capital accumulation and savings, which could be employed at the time of household necessities.

The Timor-Leste population does not explore livestock in economic and profitability terms. The animals are mostly used to sell or exchange for other products and to perform ceremonies and rituals. Livestock is seen as immobilized resource or wealth with low economic profitability (VALDEZ, 1929; ARTUR, 1926; COSTA, 1950; SILVA, 1954; FRIEDEBERG, 1974; MED, 2008).

\subsection{Economic functions}

\subsubsection{Domestic consumption}

Livestock species are a source of protein for Timor-Leste population but the consumption of meat is not done in a daily basis, instead it happens in the absence of vegetables, in the presence of guests and at the time when ceremonies are made, being chicken and pork the preferred ones. Meat dog is also consumed either at home or in the traditional restaurants, though in Viqueque only by men, being assumed that for women it is considered sacred (MIRANDA, 2011).

Despite the old descriptions that referred that pure milk and milk mixed with rice or crushed corn were consumed as a delicious manjar and that the milk left was sold (Martinho, 1936), at present, milk from local production is not drunk, while eggs consumption is restricted, mostly due to the fact that in the free ranging system it is often difficult to find and collect the eggs.

The results obtained in three sucos of Bobonaro district show that the majority of the population eat meat only once a week $(53.9 \%)$ and $31.4 \%$ twice a week (Table 6). Tapo-Memo population has higher consumption of meat than the other two sucos perhaps because this is a more urban suco. These overall results are better than the ones obtained by Deus (2011) for Letefoho sub-district, in Ermera district, in which the majority of the population eat meat once a month $(47.7 \%)$ and $29.1 \%$ twice a week. These 
Table 6. Number of times that households eat meat per week

\begin{tabular}{|c|c|c|c|c|c|c|c|c|}
\hline \multirow{2}{*}{ Number } & \multicolumn{2}{|c|}{ Tapo-Tas } & \multicolumn{2}{|c|}{ Tapo-Memo } & \multicolumn{2}{|c|}{ Aidabaleten } & \multicolumn{2}{|c|}{ Total } \\
\hline & $N^{o}$ & $\%$ & $N^{o}$ & $\%$ & $N^{o}$ & $\%$ & $N^{o}$ & $\%$ \\
\hline 0 & 0 & 0.0 & 0 & 0.0 & 7 & 20.0 & 7 & 6.9 \\
\hline 1 & 26 & 74.3 & 8 & 25.0 & 21 & 60.0 & 55 & 53.9 \\
\hline 2 & 6 & 17.1 & 21 & 65.6 & 5 & 14.3 & 32 & 31.4 \\
\hline 3 & 3 & 8.6 & 2 & 6.3 & 2 & 5.7 & 7 & 6.9 \\
\hline 4 & 0 & 0.0 & 1 & 3.1 & 0 & 0.0 & 1 & 1.0 \\
\hline Total & 35 & 100.0 & 32 & 100.0 & 35 & 100.0 & 102 & 100.0 \\
\hline
\end{tabular}

Source: Results from questionnaire survey.

modest results confirm some of the descriptions made during Portuguese colonial period that reported to be rare the Timor-Leste population eat their own domestic animals.

Regarding the livestock species used for self-consumption (Table 7), chickens, goats and pigs are the species more consumed. Regarding the households involved in livestock rearing in the survey, $66.3 \%$ eat chickens, $46.7 \%$ goats and $31.3 \%$ pigs. Sheep, buffalos and cattle are the species less utilized for self-consumption.

\subsubsection{Monetary income}

Livestock is an important source of monetary income for Timor-Leste rural population. In our study (Table 8), the majority of the households ranked livestock as their most important second and third source of income, with $40.2 \%$ and $23.5 \%$ of households, respectively, while ranked fourth as first source of income with $18.6 \%$ of households. Regarding the $1^{\text {th }}$ source of income, Tapo-Tas ranked livestock immediately after the first rank, wage work. In the other two sucos, livestock was ranked in first place as second source of income. The livestock species that contribute to livestock monetary income, stated in descending order by households, are pigs, chickens, cattle and goats, being buffalos residual. Regarding the households that are now involved in livestock rearing, $77.8 \%$ sell sheep, $66.7 \%$ goats, $60.0 \%$ chickens, $58.8 \%$ cattle, $51.8 \%$ pigs and $46.7 \%$ buffalos, as can be seen in Table 9.

Table 7. Number and percentage of households that rear livestock and use for self-consumption

\begin{tabular}{cccccccccc}
\hline & \multicolumn{2}{c}{ Tapo-Tas } & \multicolumn{2}{c}{ Tapo-Memo } & \multicolumn{2}{c}{ Aidabaleten } & \multicolumn{2}{c}{ Total } \\
\cline { 2 - 9 } & $N^{o}$ & $\%$ & $N^{o}$ & $N^{o}$ & $N^{o}$ & $\%$ & $N^{o}$ & $\%$ \\
\hline Chickens & 9 & 39.1 & 25 & 89.3 & 19 & 65.5 & 53 & 66.3 \\
Pigs & 1 & 3.4 & 15 & 55.6 & 10 & 37.0 & 26 & 31.3 \\
Goats & 1 & 33.3 & 12 & 63.2 & 8 & 34.8 & 21 & 46.7 \\
Cattle & 2 & 9.5 & 5 & 25.0 & 5 & 18.5 & 12 & 17.6 \\
Buffalos & 1 & 25.0 & 1 & 50.0 & 1 & 11.1 & 3 & 20.0 \\
Sheep & 0 & 0.0 & 0 & 0.0 & 1 & 12.5 & 2 & 22.2 \\
\hline
\end{tabular}

Source: Results from questionnaire survey.

Table 8. Livestock ranking by households as a source of income

\begin{tabular}{|c|c|c|c|c|c|c|c|c|c|c|c|c|}
\hline & \multicolumn{3}{|c|}{ Tapo-Tas } & \multicolumn{3}{|c|}{ Tapo-Memo } & \multicolumn{3}{|c|}{ Aidabaleten } & \multicolumn{3}{|c|}{ Total } \\
\hline & $N^{o}$ & $\%$ & Rank & $N^{o}$ & $\%$ & Rank & $N^{o}$ & $\%$ & Rank & $N^{o}$ & $\%$ & Rank \\
\hline $1^{\text {th }}$ source of income & 13 & 37.1 & $2^{\mathrm{a}}$ & 1 & 3.1 & $3^{\mathrm{a}}$ & 5 & 14.3 & $2^{\mathrm{a}}$ & 19 & 18.6 & $4^{\mathrm{a}}$ \\
\hline $2^{\text {th }}$ source of income & 9 & 28.1 & $2^{\mathrm{a}}$ & 16 & 50.0 & $1^{\mathrm{a}}$ & 16 & 45.7 & $1^{\mathrm{a}}$ & 41 & 40.2 & $1^{\mathrm{a}}$ \\
\hline $3^{\text {th }}$ source of income & 9 & 25.7 & $1^{\mathrm{a}}$ & 8 & 25.0 & $1^{\underline{a}}$ & 7 & 20.0 & $3^{\mathbf{a}}$ & 24 & 23.5 & $1^{\underline{a}}$ \\
\hline
\end{tabular}

Source: Results from questionnaire survey. 
Table 9. Number and percentage of households that rear livestock and sell

\begin{tabular}{cccccccccc}
\hline \multirow{2}{*}{$\begin{array}{c}\text { Livestock } \\
\text { species }\end{array}$} & \multicolumn{2}{c}{ Tapo-Tas } & \multicolumn{2}{c}{ Tapo-Memo } & \multicolumn{2}{c}{ Aidabaleten } & \multicolumn{3}{c}{ Total } \\
\cline { 2 - 10 } & $N^{o}$ & $\%$ & $N^{o}$ & $\%$ & $N^{o}$ & $\%$ & $N^{o}$ & $\%$ \\
\hline Chickens & 10 & 43.5 & 22 & 78.6 & 16 & 55.2 & 48 & 60.0 \\
Pigs & 10 & 34.5 & 21 & 77.8 & 12 & 44.4 & 43 & 51.8 \\
Goats & 3 & 100.0 & 12 & 63.2 & 15 & 65.2 & 30 & 66.7 \\
Cattle & 14 & 66.7 & 7 & 35.0 & 19 & 70.4 & 40 & 58.8 \\
Buffalos & 1 & 25.0 & 0 & 0.0 & 6 & 66.7 & 7 & 46.7 \\
Sheep & 1 & 100.0 & 0 & 0.0 & 6 & 75.0 & 7 & 77.8 \\
\hline
\end{tabular}

Source: Results from questionnaire survey.

Cash income received from livestock selling and from other economic activities is used to pay the school of children, to buy clothes, tools and food and for $36.3 \%$ of the households to buy animals to rear.

\subsubsection{Animal draught power and fertilizer}

The technologies used by subsistence agriculture are traditional ones with low modern input use. The most important vegetal activities in terms of household in crop production are maize, cassava, temporary fruits, permanent fruits, vegetables, coconuts, coffee and rice. The use of draught animal power for land preparation is mainly confined to rice while the use of animal manure to fertilize the soil is widely used in the different crops.

Buffalos and horses are used in the preparation of the soil in rice fields. In the Baucau district, Silva (2011) found that around $52.1 \%$ of farmers use buffalos and $24 \%$ use horses in rice field preparation. In the suco of Tapo-tas, the households only use tools for land preparation, in Tapo-Memo, where the rice is an important culture, around $40.6 \%$ of households use animal draught power and, in Aidabaleten, 22.9\% (Table 10). In these two sucos, the majority of the animals are owned by the households.

During the Portuguese colonization and Indonesian occupation, several attempts were made for the introduction and reinforce of animal draught power, not only for rice butalso for the other agricultural activities such as maize. For example, with the supervision of Portuguese administration, fields experiments were made to use ploughs adapted to the thin and unfertile mountainous soils (SILVA, 1910; MARTINHO, 1936; THOMAZ, 1974). During the Indonesian occupation, attempts were made, principally through transmigrants, to increase the use of draft animals, while after 1999 several programs and projects provided training and support in the use of drafts animals and on plowing (OXFAM, 2004). But all the programs were not successful. It is worth noting that ploughs are not used in Timor-Leste by the rural population since the country is outside the diffusion area of the Chinese plough, that reached Philippines and North Borneo, and also from the Indian plough, that affected Java and Bali (THOMAZ, 1973).

Table 10. Number and percentage of households using animal draught power

\begin{tabular}{ccccccccc}
\hline & \multicolumn{2}{c}{ Tapo-Tas } & \multicolumn{2}{c}{ Tapo-Memo } & \multicolumn{2}{c}{ Aidabaleten } & \multicolumn{2}{c}{ Total } \\
\cline { 2 - 9 } & No & \% & No & \% & № & \% & o & 21 \\
\hline Animal draught & 0 & 0.0 & 13 & 40.6 & 8 & 22.9 & 20.6 \\
Owned & 0 & 0.0 & 11 & 84.6 & 8 & 100.0 & 19 & 90.5 \\
Rented & 0 & 0.0 & 2 & 15.4 & 0 & 0.0 & 2 & 9.5 \\
\hline
\end{tabular}

Source: Results from questionnaire survey. 


\subsubsection{Mean of transportation}

The Timorese horse is one of the greatest richness of Timor-Leste people. From Arab origin, with elegant shape, is small and nervous, tough and of a great resistance. Having hard shell and not using horseshoe, climbs like a goat the highest mountains and the steepest barriers and goes down without hesitation the most rugged slopes, walks the difficult and dangerous paths of rural Timor-Leste. His natural aptitude is for saddle and race, although can be used for draught (VALDEZ, 1926; SILVA, 1954).

In the past, horses were used not only as transportation and draught animal power, but also in the wars between the different kingdoms and between them and the Portuguese colonial power. Horses were also used in the hunt of deer. Until the XIX century, Timor-Leste horses were well known in the South East Asia for their excellent qualities and were exported for Philippines and Dutch territories (MARTINHO, 1936).

Nowadays, it is still a valuable element for the people of mountainous and remote regions with access and isolation difficulties, facilitating form of social their access to rural and urban areas and markets and to main roads. Horses transport the owner, either farmers or sellers, and their agricultural products and inputs (our observations and SÁ, 1963; MIRANDA, 2011).

In some sucos in Baucau district, where there is no accessible road, the priest goes there monthly using the Timorese horse as mean of transport (our observations).

\subsection{Socio-cultural functions}

There has been an increased interest in the role and impact of livestock in the livelihoods of the poor in the last decade and livestock are starting to be viewed as a capital, like other forms of capital (natural, financial and so on). According to the FAO (ILRI, 1995), paying bride wealth with animals or providing animals for communal feasts or sacrifices could be considered as social functions of the livestock activity.
The social functions corresponds to the symbolic values associated to each species and the use of animals for the fulfillment of a set of rituals and social obligations (funerals, ritual slaughter, bride wealth) of families and communities, either formal and informal, and in this way animals are a mean to strengthen social networks. Livestock also play a social role by giving social and economic status to livestock owners, facilitating the access of the households to, both informal and formals, financial services, i.e. animals can be used as collateral. They are also considered a common mean of demonstrating wealth.

To fully understand the social role of livestock, it is also important to consider the role that gender plays in livestock production. To treat the pigs and chickens is considered a women's work, on the opposite the guard of buffaloes and cows, which are male property, is considered a man's job. The same division applies to its commercialization, women are in charge of small animals and men of big ones (our observations and MIRANDA, 2011). In rituals there are animals that have a feminine symbolic value and others with masculine symbolic value, for instance pigs are considered feminine social goods while buffalos and cows are masculine social goods.

Animals have also for Timor-Leste people leisure value once they are used for racing, hunting and fighting games.

During Portuguese colonial period horse racing became very pleasing to the Timorese people. The descriptions made say that bets were made, in which participated local and European people, involving sometimes appreciable amounts, horses and riders entered the racetrack under standing ovations and assistants accompanied the running of the race with great enthusiasm, especially the punters or bettors (FIGUEIREDO, 2004). Nowadays, horse racing is regaining its importance with the construction of the hippodrome in Batugadé in the border to West Timor. The last horse races were integrated in the commemorations of the 10th anniversary of the independence of the country and counted with Australia, Indonesia and Timor- 
Leste participation. The horse racing is seen as important to tourism and economic development (NARCISO, 2012).

The deer hunting in Timor-Leste was done in the past and in some zones is still done nowadays. In the past, horses were used in this activity in which animals were hunted with a javelin. The old descriptions tell us about the ability of hunters in handling simultaneously the horse and the javelin when tracking down and killing the deer.

Cock fighting is one of the older traditions of Timor-Leste and one of the games preferred by Timor-Leste people from all regions. It is a popular masculine pastime where women are not allowed to participate (HICKS, 2001). Cocks are admired in Timor because of their courage and perseverance and the courage of a man is sometimes compared with that of a cock, while a coward is called a hen. The cock fighter is inseparable from his owner and it is common to see men carrying cocks under their arms as precious possessions.

Cockfights are held on any social occasion when men get together, from the spontaneous to more formal occasions and are part of many weekly markets. In the past, the animals represented always two factions or two villages and not only fight for their owners, but also for the two villages or kingdoms. There were two fights, between the two cocks and between the bets made by people belonging to the two factions.

It is a gambling game and a very important leisure activity in Timor-Leste. It is a fight to first blood, it makes it very quick, 10-20 seconds from the wind-up to first blood, and there is always someone on site, to stitch up the loser and he can go home to the cooking pot or to stud. East Timorese people says gambling is in their blood after centuries of cock-fighting and many times lose all their belongings in an afternoon of betting in cock fighting (BRAGA, 1935; FONTOURA, 1940; SÁ, 1963).

The Portuguese colonial government tried, but was not able to end this practice, and instead implemented a tax to its realization, thus becoming a source of income to the state. Beside the fact that many tais designs include the cock, its representation in the coins (10 cêntimos) is a tribute to the culture and to the courage of Timorese's people to fight over time to achieve their independence. The portuguese poet Ruy Cinatti, also in a tribute to Timor-Leste culture make the following poem about cock fighting.

\author{
A Luta de Galos \\ (desporto número um dos Timorenses) \\ Galo doido, meu brinquedo, \\ Aninhado nos meus braços. \\ Sinto o meu coração preso \\ Só de pensar no combate. \\ Pintei-lhe de verde as penas \\ Só a pensar no combate. \\ The cock fighting \\ (Timorese number one sport) \\ Cock crazy, my toy, \\ Tucked away in my arms. \\ I feel my heart stuck \\ Just thinking about the fight. \\ I painted its feathers of green \\ Just thinking about the fight \\ in "Um Cancioneiro Para Timor" - \\ Ruy Cinatti, 1996
}

The description made before the second world war say that the Timor-Leste people, with his patience and perseverance, manufactures small articles from the black and white horns of the buffalos, such as dolls, utensils of ménage and adornments, which are a demonstration of his skills and artistic sense (FONTOURA, 1940; BRAGA, 1935). Nowadays there are some handcraft made with animal raw materials such as skins and horns, used to build drums and other artifacts.

Cattle and special buffalos are owned as an index of wealth, outward sign of wealth, often created by mere ostentation, without the intention to extract from it any net income. 
Cattle ownership largely determines social status in village communities. Owners of large numbers of cattle are important people in society and are always involved in important village events. The Timorese evaluates the wealth of a chief, boss, or a simple man by jewelry, clothes and animals he has, and the buffalo always enter in this calculation with a significant weight (CRUZ, 2003).

For all the reasons, farmers are reluctant to slaughter animals, namely cattle and buffalos, for their own consumption, except during funerals, festivals or wedding celebrations. Occasionally, a farmer will slaughter an animal but will negotiate with relatives, friends and neighbors beforehand to ensure that the excess can be sold.

Cattle are more valuable than goats, sheep and pigs from a social point of view but they are not as easy to sell. Goats, sheep and pigs can be sold easily whenever farmers face economic difficulties. Ruminants are important for meeting the needs of major local markets throughout the territory (CRUZ, 2003).

According to Cinatti (1987), in Timorese society, the buffalo is one of the most useful/helpful animals. The buffalo is a "multi-task" animal: it works, give prestige and it is used in ceremonies. As a working animal, it is indispensable to prepare the lowland rice fields; it gives prestige as buffalos are used as a measure of wealth and as simple method of save accumulation.

During the last century, several authors mention the Buffalo as the sacrificial animal per excellence in agricultural, weddings and burial rituals (VALDEZ, 1927; MARTINHO, 1936;
THOMAZ, 1974; SÁ, 1963). Martinho (1936) refers that "estilos" of "Ocoí-Mate" cause the dead of some thousands of animals, buffaloes, pigs and goats around the year. Even nowadays buffalos are part of the "barlaque" and are indispensable in "estilos" of Ocoí-Mate. The estilo of "OcoíMate" is a memorial service for departed souls. Animistic and superstitions says that the soul of the deceased does not feel quiet if relatives, in funeral ceremonies, not sacrifice a few buffalos.

The buffalo meat is of inferior quality but in Timor people makes extensive use of it. Their meat is appreciated in most of the territory. In fact, in terms of meat quality, the buffalo is lower than those of cattle, but in the traditional system, presents an opposite meaning, i.e., taking as an example, the dowry and the funerals, the buffalo has more symbolic importance than that cattle. Another dimension considered important to treat this animal is the size and length of horns. The largest value resides in the length of the horns and not on the size and volume of the body.

One of the social functions is the use of animals for the fulfillment of a set of rituals and social obligations (funerals, ritual slaughter, bride wealth) of families and communities, either formal and informal.

For the three sucos studied, the animals that are more relevant for traditional ceremonies and festivities "estilos" are pigs and cattle followed by chicken and goats. Cattle are more important for Tapo-Tas and Aidabaleten, while pigs and chicken are for Tapo-Memo (Table 11). Regarding the households that are involved in livestock rearing, $51.5 \%$ use cattle, $47.0 \%$ pigs, $46.7 \%$ goats and

Table 11. № of households which use livestock animals for ceremonies and festivities

\begin{tabular}{cccccccccc}
\hline \multirow{2}{*}{ Activities } & \multicolumn{2}{c}{ Tapo-Tas } & \multicolumn{2}{c}{ Tapo-Memo } & \multicolumn{2}{c}{ Aidabaleten } & \multicolumn{2}{c}{ Total } \\
\cline { 2 - 9 } & $N^{o}$ & $\%$ & $N^{o}$ & $\%$ & $N^{o}$ & $\%$ & $N^{o}$ & $\%$ \\
\hline Chickens & 4 & 17.4 & 18 & 64.3 & 2 & 6.9 & 24 & 30.0 \\
Pigs & 9 & 31.0 & 20 & 74.1 & 10 & 37.0 & 39 & 47.0 \\
Goats & 1 & 33.3 & 12 & 63.2 & 8 & 34.8 & 21 & 46.7 \\
Cattle & 10 & 47.6 & 11 & 55.0 & 14 & 51.9 & 35 & 51.5 \\
Buffalos & 0 & 0.0 & 0 & 0.0 & 1 & 11.1 & 1 & 6.7 \\
Sheep & 0 & 0.0 & 0 & 0.0 & 1 & 12.5 & 1 & 11.1 \\
\hline
\end{tabular}

Source: Results from questionnaire survey. 
$30.0 \%$ chickens. The animals used are cooked, often in a special way, and shared by participants.

Among the several ceremonies performed around the year, it is worth to highlighting the "Finados" which is celebrated by $99 \%$ of respondents followed by the day of All Saints (Table 12).

Almost all families celebrate some kind of worships before or/and after harvest the main agricultural production and they do that mainly as a household or family ceremony and more than of half of them as a more large communal ceremony (Table 13).

Beside the main vegetable production, cattle and buffalos are also subject to worship and these occur mainly in Tapo-Tas which is in the mountain and the most rural of them (Table 14).

In all districts the communities still perform a set of rituals with a "propitiatory" nature (before sowing, after harvest, in the case of pests, to ask for rain or to ask to stop the rain ...) and even technological innovations from outside the community have to be integrated into the local culture, such as the ritual of Fasi karau ain (washing the feet of the buffalo) that in the district Viqueque continues to be done, not only to animals but also to tractors (MIRANDA, 2011).

Beyond the prayers, songs, dances and other gifts as gold, money and areca, the people proceed

Table 12. Rituals performed every year

\begin{tabular}{lcccccccc}
\hline & \multicolumn{2}{c}{ Tapo-Tas } & \multicolumn{2}{c}{ Tapo-Memo } & \multicolumn{2}{c}{ Aidabaleten } & \multicolumn{2}{c}{ Total } \\
\cline { 2 - 8 } & № & \% & No & \% & № & \% & № & \% \\
\hline Build and inaugurate sacred house & 10 & 28.6 & 5 & 15.6 & 8 & 22.9 & 23 & 22.5 \\
Remove mourning (desluto) & 9 & 25.7 & 9 & 28.1 & 7 & 20.0 & 25 & 24.5 \\
All Sould's day (finados) & 35 & 100.0 & 32 & 100.0 & 34 & 97.1 & 101 & 99.0 \\
All Saints day & 24 & 68.6 & 30 & 93.8 & 25 & 71.4 & 79 & 77.5 \\
Funerals & 12 & 34.3 & 6 & 18.8 & 8 & 22.9 & 26 & 25.5 \\
Weddings & 6 & 17.1 & 5 & 15.6 & 4 & 11.4 & 15 & 14.7 \\
Call the rain & 21 & 60.0 & 12 & 37.5 & 6 & 17.1 & 39 & 38.2 \\
Burning grass & 4 & 11.4 & 9 & 28.1 & 3 & 8.6 & 16 & 15.7 \\
\hline
\end{tabular}

Source: Results from questionnaire survey.

Table 13. Type of worship made

\begin{tabular}{lccccccccc}
\hline & \multicolumn{3}{c}{ Tapo-Tas } & \multicolumn{2}{c}{ Tapo-Memo } & \multicolumn{2}{c}{ Aidabaleten } & \multicolumn{2}{c}{ Total } \\
\cline { 2 - 9 } & $N^{o}$ & $\%$ & $N^{o}$ & $\%$ & $N^{o}$ & $\%$ & $N^{o}$ & $\%$ \\
\hline Worships before and after harvest & 34 & 97.1 & 30 & 93.8 & 35 & 100.0 & 99 & 97.1 \\
Individual worship & 32 & 94.1 & 30 & 93.8 & 34 & 97.1 & 96 & 95.0 \\
Family worship & 25 & 73.5 & 19 & 59.4 & 33 & 94.3 & 77 & 76.2 \\
Community worship & 23 & 67.6 & 16 & 50.0 & 18 & 51.4 & 57 & 56.4 \\
\hline
\end{tabular}

Source: Results from questionnaire survey.

Table 14. Main agricultural activities subject to worship

\begin{tabular}{cccccccccc}
\hline & \multicolumn{2}{c}{ Tapo-Tas } & \multicolumn{2}{c}{ Tapo-Memo } & \multicolumn{2}{c}{ Aidabaleten } & \multicolumn{2}{c}{ Total } \\
\cline { 2 - 9 } & $N^{o}$ & $\%$ & $N^{o}$ & $\%$ & $N^{o}$ & $\%$ & $N^{o}$ & $\%$ \\
\hline Maize & 34 & 100.0 & 31 & 96.9 & 30 & 85.7 & 95 & 94.1 \\
Rice & 8 & 23.5 & 32 & 100.0 & 33 & 94.3 & 73 & 72.3 \\
Coffee & 22 & 64.7 & 2 & 6.3 & 1 & 2.9 & 25 & 24.8 \\
Cattle & 18 & 52.9 & 2 & 6.3 & 4 & 11.4 & 24 & 23.8 \\
Buffalos & 9 & 26.5 & 1 & 3.1 & 3 & 8.6 & 13 & 12.9 \\
Fishing & 3 & 8.8 & 2 & 6.3 & 21 & 60.0 & 26 & 25.7 \\
\hline
\end{tabular}

Source: Results from questionnaire survey. 
to the sacrifice of animals to offer to the spirits or to see in his bowels how the harvest will be.

This practice highlights the importance of the investment that is made in agriculture, despite the low number of animals that each family has, they do not fail to meet their ritual obligations, providing animals for communal feasts or sacrifices, in order to try to ensure a good harvest. As gift/scarified in ceremonies, the animals most used are chicken and pigs (Table 15). The buffalos are used only by about $3 \%$ of the households.

If we compare these findings with the past documents seems that buffalos are losing importance but according our informants the decreased in using Buffalos in ceremonies is not because they are not important and desirable but due to the fact that they are very expensive and only affordable on very rare occasions and for very few families. This idea confirmed the description made by Claudine Friedberg: she mentioned that "During my presence, these rituals were no longer performed, undoubtedly because one no longer could afford them" referring the 'cooling' ritual in which a piglet and a goat were traditional slaughtered (FRIEDBERG, 1989).

\section{Conclusions}

In sum, we can identify in the literature written about Timor-Leste and in our research that livestock had in the paste and has nowadays different functions for Timor-Leste households.
Nowadays, livestock is seldom used on agricultural works, such as buffalos and horse in rice land preparation, but the manure is often used as organic fertilizer. As a mean of transportation, horses are still used, mainly in mountainous regions, but much less than were in the past. However, when families do not have another mean of transport, use the animals mainly for cargo.

Regarding consumption, livestock species are a source of protein for Timorese even though the consumption of meat is not done in a daily basis. The livestock species used for self-consumption are mainly small animals, chickens, pigs and goats. At present, milk from local production is not drunk, although in past times buffalo milk was consumed, but this use was lost during the independence war. The Timor-Leste people use the black and white horns of the buffalos to manufacture articles such as dolls, utensils of ménage and adornments.

Concerning domestic finances, animals are very important as a mean of asset savings that can be converted into cash when family needs arise. In many rural regions, livestock stocks are a source of asset accumulation. This source can be mobilized to satisfy some unexpected expenditures such as children school fees, bride wealth, illness, etc. Cattle are owned as an index of wealth, outward sign of wealth, often created by mere ostentation, without the intention to extract from it any net income. This ownership largely determines social status in village communities.

Table 15. Gifts offered in the worships

\begin{tabular}{lcccccccc}
\hline & \multicolumn{2}{c}{ Tapo-Tas } & \multicolumn{2}{c}{ Tapo-Memo } & \multicolumn{2}{c}{ Aidabaleten } & \multicolumn{2}{c}{ Total } \\
\cline { 2 - 8 } & $N^{o}$ & $\%$ & $N^{o}$ & $\%$ & $N^{o}$ & $\%$ & $N^{o}$ & $\%$ \\
\hline Cock and hen & 31 & 88.6 & 31 & 96.9 & 32 & 91.4 & 94 & 92.2 \\
Pigs & 23 & 65.7 & 27 & 84.4 & 28 & 80.0 & 78 & 76.5 \\
Goats & 8 & 22.9 & 3 & 9.4 & 17 & 48.6 & 28 & 27.5 \\
Eggs & 13 & 37.1 & 6 & 18.8 & 24 & 68.6 & 43 & 42.2 \\
Cattle & 4 & 11.4 & 1 & 3.1 & 4 & 11.4 & 9 & 8.8 \\
Buffalos & 2 & 5.7 & 1 & 3.1 & 0 & 0.0 & 3 & 2.9 \\
Palm wine (tua mutin or tua sabu) & 9 & 25.7 & 5 & 15.6 & 3 & 8.6 & 17 & 16.7 \\
Areca e bétele & 27 & 77.1 & 29 & 90.6 & 21 & 60.0 & 77 & 75.5 \\
Money & 16 & 45.7 & 10 & 31.3 & 19 & 54.3 & 45 & 44.1 \\
Gold & 5 & 14.3 & 4 & 12.5 & 2 & 5.7 & 11 & 10.8 \\
\hline
\end{tabular}

Source: Results from questionnaire survey. 
Among the social functions, one is the use of animals for the fulfillment of a set of rituals and social obligations (funerals, ritual slaughter, bride wealth) of families and communities, either formal and informal. The most relevant animals for traditional ceremonies and festivities "estilos" are pigs and cattle followed by chicken and goats.

From our observations, interviews and talks with local people, it is worthwhile to mention the importance given by households to the livestock social functions. However, many of these functions are often ignored when estimating the total contribution of livestock to wealth and wellbeing of Timor-Leste households. The economic value of the livestock social functions are difficult to evaluate and specific research needs to be done in order to better understand and assess the role of livestock in the wellbeing and in development of rural communities in Timor-Leste and to quantify its economic value.

\section{References}

ARTUR, R. Politica, Administração e Trabalho na Província de Timor - A organização agrária, Boletim da Agencia Geral das Colónias, ano II, no 9, Lisboa, p. 53-86, 1926.

BRAGA, P. A Terra, a Gente e os Costumes de Timor. Cadernos Coloniais, n. 7, Edições Cosmos, Lisboa, 1935.

CINATTI, R. Motivos artísticos Timorenses e a sua integração, Lisboa, 1987.

. Um Cancioneiro Para Timor. Lisboa: Editorial Presença, 1996.

CONCEIÇÃO, F. Major Findings of Active Diseases Surveillance on Priority Animal Diseases of TimorLeste, Communication presented at the final project workshop, MAF, 2012.

COSTA, M. Pecuária, Defesa Nacional, ano xvii, n. 193194, Lisboa, p. 47- 48, 1950.

CRUZ, C. J. Livestock development in east timor, in agriculture: new directions for a new nation - East Timor (Timor-Leste)", Edited by Helder da Costa, Colin Piggin, Cesar J da Cruz and James J Fox, ACIAR Proceedings No. 113, 2003.
DEUS, C. C. Impacto do desempenho da Cooperativa Café Timor na satisfação e qualidade de vida dos seus membros. Tese de Mestrado em Gestão, Universidade de Évora, Évora, 2011.

DNE. Census da população, Direcção Nacional de Estatística, Díli, 2006.

DNE. Census da população, Direcção Nacional de Estatística, Díl, 2011i.

FIGUEIREDO, F. Timor a presença Portuguesa: 1769-1945, Dissertação de Doutoramento em História, Faculdade de Letras, Universidade do Porto, 2004.

FONTOURA, A. O trabalho dos Indígenas de Timor. Congresso do Mundo Português, v. XVI, tomo 3, III Secção, Lisboa, p. 14-95, 1940.

FRIEDBERG, C. Agricultures Timoraises. Etudes rurales, n. 53-56, p. 375-405, 1974.

FRIEDBERG, C. Social relations of territorial management in light of Bunaq farming rituals. In: Bijdragen tot de Taal-, Land- en Volkenkunde, Rituals and SocioCosmic Order in Eastern Indonesian Societies; Part I Nusa Tenggara Timur 145 (1989), no: 4, Leiden, 548563. This PDF-file was downloaded from http://www. kitlv-journals.nl.

HICKS, D. Blood and feathers - masculine identity in East Timorese cockfighting, World and I, 2001.

ILRI (International Livestock Research Institute). Livestock Policy Analysis, ILRI Training Manual 2, ILRI, Nairobi, Kenya, p. 264, 1995.

MARTINHO, J. S. Medidas tendentes à protecção e selecção das espécies pecuárias existentes na Colónia e desenvolvimento daquelas que melhor satisfaçam a indústria pecuária, em primeira conferência económica do império colonial português, $3^{\text {a }}$ Comissão, Ministério das Colónias, Lisboa, p. 1-10, 1936.

MED (Ministério da Economia e Desenvolvimento). "Relatório de Estado da Nação", Volume IV, Relatório de Situação de Sector, Grupo da Produção, Díli, TimorLeste, 2008.

MIRANDA, S. Género e Agricultura em Quatro Distritos de Timor-Leste (Bobonaro, Ermera, Manatuto e Viqueque), Secretaria de Estado para a Promoção da Igualdade, Díli, Timor-Leste, 2011.

MOYO, S. and SWANEPOEL, F. J. C. Multifuncionality of livestock in developing communities. In: The Role of Livestock in Developing Communities: Enhancing Multifunctionality, edited by Frans Swanepoel, Aldo Stroebel and Siboniso Moyo, Co-published 
by The Technical Centre for Agricultural and Rural Cooperation (CTA) and University of the Free State, 2010.

NARCISO, C. Corridas de cavalos (Horses racecourse stadium at Batugadé, in Bobonaro, East Timor), 2012.. http://www.youtube.com/watch?v=yBtVdJG7_1w\&fe ature $=$ plcp $($ consulted 2012.06.30)

OIE. "World animal health status in 2004". Reports by countries, 2004. http://web.oie.int/eng/info/old_en_ sam.htm (consulted 2012.06.30)

OIE (2012) http://web.oie.int/wahis/public. php?page $=$ country_status\&year $=2011 \quad$ (consulted 2012.06.30)

OTTE and CHILONDA. "Animal health economics: an introduction", Livestock Information, Sector Analysis and Policy Branch, Animal Production and Health Division, FAO, 2000.

OUMA, E. A., GIDEON A. O. and STEVEN J. S. "Cattle as assets: assessment of non-market benefits from cattle in smallholder kenyan crop- livestock systems", Proceedings of the 25th International Conference of Agricultural Economists (IAAE), 16-. 22 August, Durban, South Africa, 2003.

OXFAM. "Overview of the rice sector in Timor-Leste", OXFAM, Díli, 2004.

SÁ, A. de. Timor, Sociedade de Geografia de Lisboa, Semana do Ultramar, Reeditado por TimorAgri, 1963.

SILVA, J. A mão de obra em Timor. Breves memórias sobre o seu território, clima, produção, usos de costumes indígenas, industria, agricultura e comércio. Lisboa: A Editora, 1910, p. 3-49.

SILVA, H. Panorama Pecuária de Timor, Revista de Ciências Veterinárias, v. XLIX, p. 348-349, p. 157-187, 1954.
SILVA, H. Prospecção parasitológica em Timor. Subsídios para o estudo da fauna parasitológica dos seus animais domésticos, Junta de Investigação do Ultramar. Estudos, ensaios e documentos, n. 76, 1960.

SILVA, J. Desenvolvimento e recursos humanos no sector da orizicultura no distrito de Baucau em Timor-Leste. Dissertação de Mestrado, Universidade de Évora, Évora, 2011.

SMITH, O. B. Small-ruminant feeding systems for small-scale farmers in humid West Africa. In: The complementarity of feed resources for animal production in Africa, African Feed Resources Network, Addis Ababa, 1992.

THOMAZ, L. O programa económico de Timor. Revista Militar, ano XXVI, n. 8/9, Lisboa, p. 1-10, 1974.

THOMAZ, L. F. R. Vida Rural Timorense. Geographica, ano IX, Lisboa, Sociedade de Geografia, n. 33, p. 3-26, 1973.

TIMOR AGRI. East Timor Agriculture Network. Dili, Timor Leste, 2004.

VALDEZ, J. A. O Cavalo de Timor. Boletim da Agência Geral das Colónias, ano II, n. 17, 1926, p. 7-10, 1926.

- A Pecuária de Timor. Boletim da Agência Geral das Colónias, ano III, Lisboa, Agência Geral das Colónias, n. 19, p. 85-88, jan. 1927.

. Timor e a sua pecuária. Boletim da Agência Geral das Colónias, ano V, Agência Geral das Colónias, Lisboa, n. 54, p. $55-71,1929$.

WHO. Mapping of vector-borne diseases in the SouthEast Asia Region. Communicable Disease Newsletter, v. 9, n. 1, p. 1-2, 2012. 